\title{
The prognostic value of measurement of high-sensitive cardiac troponin T for mortality in a cohort of stable chronic obstructive pulmonary disease patients
}

Anke Neukamm, Gunnar Einvik², Arne Didrik Høiseth, Vidar Søyseth', Nils Henrik Holmedahl', Natalia Kononova ${ }^{5}$ and Torbjørn Omland ${ }^{2,5^{*}}$

\begin{abstract}
Background: Cardiovascular disease (CVD) is a common comorbidity in chronic obstructive pulmonary disease (COPD). Cardiac troponin (cTn) elevation, indicating myocardial injury, is frequent during acute COPD exacerbations and associated with increased mortality. The prognostic value of circulating CTnT among COPD patients in the stable state of the disease is still unknown.

The purpose of the present study was to assess the association between circulating CTnT measured by a high sensitive assay (hs-cTnT) and all-cause mortality among patients with stable COPD without overt CVD.

Methods: In a prospective cohort study we included 275 patients from the Akershus University Hospital's outpatient clinic and from Glittre, a pulmonary rehabilitation clinic. COPD-severity and cardiovascular risk factors were assessed, and time to all-cause death was recorded during a mean follow-up time of 2.8 years.

Results: One hundred-eighty patients (65\%) had hs-cTnT concentrations $\geq$ the level of detection $(5.0 \mathrm{ng} / \mathrm{L})$ and 66 patients (24\%) had hs-cTnT above the normal range ( $\geq 14.0 \mathrm{ng} / \mathrm{L})$. In total, 47 patients (17\%) died. hs-cTnT concentrations in the ranges $<5.0,5.0-13.9$ and $\geq 14 \mathrm{ng} / \mathrm{L}$ were associated with crude mortality rates of $2.8,4.4$ and 11.0 per 100 patient-years, respectively. In adjusted analyses the hazard ratios (95\% confidence intervals) for death were $1.7(0.8-3.9)$ and 2.9 (1.2-7.2) among patients with hs-cTnT concentrations 5.0-13.9 and $\geq 14 \mathrm{ng} / \mathrm{L}$, respectively, compared to patients with hs-cTnT $<5.0 \mathrm{ng} / \mathrm{L}$.

Conclusions: hs-cTnT elevation is frequently present in patients with stable COPD without overt CVD, and associated with increased mortality, independently of COPD-severity and other cardiovascular risk factors.
\end{abstract}

Keywords: Chronic obstructive pulmonary disease, Cardiac troponin T, Mortality, Biomarker

\section{Background}

Chronic obstructive pulmonary disease (COPD) is a progressive disease with increasing prevalence [1]. COPD is associated with severe comorbidities that influence prognosis, including cardiovascular disease (CVD) [2]. While smoking is a shared risk factor for both COPD and CVD, COPD has also been described as an independent risk factor for the development of CVD [3, 4] and it has repeatedly been

\footnotetext{
* Correspondence: Torbjorn.omland@medisin.uio.no

${ }^{2}$ Division of Medicine, Akershus University Hospital, Lørenskog, Norway

${ }^{5}$ Institute of Clinical Medicine, University of Oslo, Oslo, Norway

Full list of author information is available at the end of the article
}

shown that CVD is more common among COPD patients than in the general population [5-7]. Systemic inflammation, oxidative stress and hypoxemia may contribute to the development of CVD in this patient group [8].

Measurement of cardiac specific troponins (cardiac troponin $\mathrm{T}$ and troponin $\mathrm{I}(\mathrm{cTnT}, \mathrm{cTnI})$ ) is incorporated in the definition and diagnosis of acute myocardial infarction (MI) [9]. Other acute cardiac and non-cardiac conditions not directly related to MI have also been associated with higher troponin levels, such as acute heart failure, peri-/myocarditis, pulmonary embolism, renal failure, sepsis, and even strenuous exercise [10, 11]. In 
addition, chronic, low-grade elevations of cardiac troponins have been observed in patients with stable coronary artery disease and chronic heart failure $[12,13]$. Previously, COPD has been associated with elevated cTnT in the exacerbated, as well as in the stable state of the disease [14-17]. Moreover, with highly sensitive methods available, it has been shown that even levels of cTnT in the low-concentration range are associated with increased mortality among patients with acute exacerbations of COPD (AECOPD) $[14,15,18]$. However, to the best of our knowledge, the association between cTnT measured during the stable state of the disease and mortality has not been studied previously. Accordingly, the objective of the present study was to relate cTnT measured in patients with stable COPD and mortality while controlling for relevant confounding factors.

\section{Methods}

\section{Design and participants}

This was a prospective cohort study including 275 patients with stable COPD from the outpatient clinic at the Akershus University Hospital and from Glittre Hospital, a pulmonary rehabilitation hospital in Akershus, Norway. Patients were included from June 2009 through July 2013 and January 2010 through June 2011, respectively. A stable state was defined as not having an AECOPD or being recovered from an AECOPD at least 3 weeks prior to inclusion. Patients with previously established CVD (defined as history of MI, angina pectoris, percutaneous coronary intervention or stroke) were excluded $(n=16)$ in the present analyses. Further details of the recruitment procedure have been reported previously $[16,19,20]$.

\section{Data collection at baseline}

History of smoking, hypertension, diabetes and use of antiplatelet therapy as well as function status by the modified Medical Research Council (mMRC) dyspnoea scale were obtained by interview. Systolic blood pressure, weight and height were measured, and BMI calculated. The presence of left ventricular hypertrophy (LVH, Sokolow-Lyon criteria), pathological Q- and T-waves and resting heart rate were evaluated by two physicians (AN, GE), blinded by troponin levels and outcome. The arterial partial pressures of oxygen and carbon dioxide $(\mathrm{PaO} 2$ and $\mathrm{PaCO} 2)$ were obtained from radial arterial punctures and post-bronchodilatory spirometry measures, i.e. forced expiratory volume in 1 second (FEV1) and forced vital capacity (FVC) were registered from the best of 3 measures. Six-minute walking distance (6MWD) was performed. Haemoglobin and leucocytes count were analysed from antecubital venous punctures, while serum and plasma samples were stored at $-80{ }^{\circ} \mathrm{C}$ pending analysis of creatinine and hs-cTnT (cobas e 411 immunoanalyzer, Roche diagnostics). According to the manufacturer of the
hs-cTnT assay, the lower limit of detection is $5.0 \mathrm{ng} / \mathrm{L}$, and the $99^{\text {th }}$ percentile in a sample of 533 healthy volunteers was $14 \mathrm{ng} / \mathrm{L}$. The lowest hs-cTnT level with $10 \%$ coefficient of variation was $13 \mathrm{ng} / \mathrm{L}$.

\section{Study endpoint}

Mortality data was gathered from the National Population Registry, which is based on a unique personal identification number for all Norwegians. The censoring data (end of follow-up) was set to November 17, 2014.

\section{Ethical considerations}

The study was approved by the Data Protection Authority, and reviewed by the Regional Committee for Research Ethics. All patients gave their written consent prior to participation.

\section{Statistical analyses}

hs-cTnT levels were categorized in three groups: <5.0 ng/ $\mathrm{L}, 5.0-13.9 \mathrm{ng} / \mathrm{L}$ and $\geq 14 \mathrm{ng} / \mathrm{L}$. Additionally, the data was analyzed using hs-cTnT as a continuous variable, logarithmically transformed due to skewed distribution. Assuming a mortality rate at 24 months of follow-up of 0.25 in patients with troponin $\mathrm{T}$ level values $>0.013 \mathrm{ng} / \mathrm{L}$ (assumed $n=100$ ) and 0.13 in patients with troponin level values $<0.013 \mathrm{ng} / \mathrm{mL}$ (assumed $n=100$ ), the study will have $>80 \%$ power to detect a significant difference (alpha $=0.05)$.

The analyses were performed in four steps. First, univariate associations between hs-cTnT and covariates at baseline were assessed using Chi-square test, one-way analysis of variance or Kruskal-Wallis test for categorical and continuous variables, respectively. Second, ageadjusted log-rank test for mortality was performed for covariates if the association between the covariate and hs-cTnT in the univariate analysis had a $\mathrm{p}$-value $<0.2$. Third, if the age-adjusted log-rank test for mortality for each covariate revealed a p-value $<0.2$, we calculated the crude and adjusted mortality rate ratios (MRR) between each level of hs-cTnT for each corresponding covariate. The Mantel-Haenszel test was used to evaluate the statistical significance by the MRR. Moreover, we tested if the Mantel-Haenszel test revealed a p-value $<0.05$ for homogeneity. Fourth, if the p-value of the Mantel-Haenszel test was $<0.2$, the covariate was included in a multivariate proportional hazard Cox regression model subsequently reduced by backward elimination. Covariates were removed from the model if the association between a covariate and mortality were non-significant and removal of the covariate changed the estimate of coefficient between hs-cTnT and mortality $<20 \%$.

In the first step, the univariate associations between hs-cTnT and these covariates were assessed: Gender, age, $\mathrm{FEV}_{1} / \mathrm{FVC}$-ratio, $\mathrm{FEV}_{1}, \mathrm{BMI}, \mathrm{LVH}$, pathological Q 
and T-wave on the electrocardiogram, history of hypertension, history of diabetes, use of antiplatelet therapy, smoking status, number of tobacco pack years, heart rate, systolic $\mathrm{BP}$, haemoglobin, leucocytes, $\mathrm{PaO} 2, \mathrm{PaCO} 2$ and 6MWD. Glomerular filtration rate (GFR) was estimated by the Cockcroft-Gault equation [21]. Before the subsequent steps, continuous covariates were categorized. The limits were guided by clinical practice and distribution in the sample: Age was categorized in three groups: $<62$ years, $62-66$ years and $\geq 67$ years. Spirometry measures were categorized by GOLD class, heart rate in $<71 /$ min and $\geq 71 /$ min (median value), systolic blood pressure in $<120$ and $\geq 120 \mathrm{mmHg}$ (median value), leucocyte count in $<7 \times 10$ and $\geq 7 \times 10^{9} / \mathrm{L}$ (median value), GFR in $<45,<60$ and $\geq 60 \mathrm{~mL} / \mathrm{min}$, partial pressure of oxygen $(\mathrm{PaO} 2)$ in $<8$ $\mathrm{kPa}$ and $\geq 8 \mathrm{kPa}$ and 6 minute walking distance was categorized in $<450$ and $\geq 450 \mathrm{~m}$ (median value), respectively. The analyses were performed using STATA 13.1 (Stata Corp LP, Texas, USA) and SPSS (Version 20; IBM Corp, New York, NY, USA).

\section{Results}

The median hs-cTnT was $6.3 \mathrm{ng} / \mathrm{L}$ (interquartile range 5-13 ng/L). The prevalences of patients having hs-cTnT
$<5.0 \mathrm{ng} / \mathrm{L}, 5.0-13.9 \mathrm{ng} / \mathrm{L}$ and $\geq 14 \mathrm{ng} / \mathrm{L}$ were $35 \%, 41 \%$ and $24 \%$, respectively. Mean age (SD) at inclusion was 64 (7.2) years and 146 (53\%) were female. Univariate associations between hs-cTnT categories and covariates using the inclusion criterion of a $p$-value $<0.2$ were observed for the following covariates (Table 1): Age, gender, GOLD class, history of hypertension and diabetes, current smoking, systolic blood pressure, heart rate, pathological Q-wave, $\mathrm{PaO}$, leucocyte count, GFR, 6MWD and mMRC-score.

The median time to death or censoring time was 2.8 years. 47 patients $(17.1 \%)$ died during the followup period. The crude mortality rates per 100 patientyears (95\% confidence interval) were 2.8 (1.4-5.3), 4.4 (2.7-7.0) and $11.0(7.2-16.9)$ in patients with hs$\mathrm{cTnT}<5.0 \mathrm{ng} / \mathrm{L}, \quad 5.0-13.9 \mathrm{ng} / \mathrm{L}$ and $\geq 14 \mathrm{ng} / \mathrm{L}$, respectively.

Age-adjusted associations between covariates and mortality were observed for history of diabetes, GOLDclass, pathological Q-wave, leucocyte count, creatinine, heart rate, $6 \mathrm{MWD}$ and $\mathrm{mMRC}>2$ (Table 2). The number of deaths and mortality rates across hs-cTnT levels, stratified by the covariates significantly associated with hs-cTnT, are shown in Table 3.

Table 1 Distribution of TnT by relevant covariates at baseline

\begin{tabular}{|c|c|c|c|c|}
\hline \multirow[t]{2}{*}{ Covariate } & \multicolumn{3}{|c|}{ High sensitivity Troponin T, ng/L } & \multirow[t]{2}{*}{$p$-value ${ }^{*}$} \\
\hline & $<5.0(n=95)$ & $5.0-13.9(n=114)$ & $\geq 14.0(n=66)$ & \\
\hline Age, years, mean (SD) & $62(7.3)$ & $64(6.7)$ & $67(7.2)$ & $<0.001$ \\
\hline Female, n (\%) & $64(67)$ & $56(49)$ & $26(39)$ & $<0.001$ \\
\hline BMI, mean (SD) & $24.7(5.1)$ & $24.7(5.4)$ & $24.5(5.4)$ & 0.962 \\
\hline GOLD class III/IV, n (\%) & $46(48)$ & $60(53)$ & $51(77)$ & 0.001 \\
\hline Hypertension, n (\%) & $32(34)$ & $36(32)$ & $36(55)$ & 0.006 \\
\hline Diabetes, n (\%) & $4(4)$ & $1(1)$ & $9(14)$ & 0.001 \\
\hline Current smoking, n (\%) & $34(36)$ & $29(26)$ & $11(17)$ & 0.025 \\
\hline Pack years, mean (SD) & $35(16.1)$ & $35(16.9)$ & $37(19.5)$ & 0.686 \\
\hline Systolic BP, mmHg mean (SD) & $132(21.9)$ & $138(20.1)$ & $138(19.5)$ & 0.080 \\
\hline Hemoglobin, g/dL mean (SD) & $14.1(1.2)$ & $14.3(1.1)$ & $15.7(13.7)$ & 0.285 \\
\hline Heart rate per min, mean (SD) & $70(13.3)$ & $71(12.9)$ & 75 (13.9) & 0.067 \\
\hline LVH, n (\%) & $1(1)$ & $5(5)$ & $2(3)$ & 0.358 \\
\hline Pathologic Q-wave, n (\%) & $5(5)$ & $6(5)$ & $9(14)$ & 0.067 \\
\hline Use of antiplatelet therapy, n (\%) & $10(10)$ & $12(11)$ & $5(8)$ & 0.781 \\
\hline $\mathrm{PaO} 2, \mathrm{kPa}$, mean (SD) & $9.0(1.1)$ & $9.3(1.3)$ & $8.9(1.3)$ & 0.058 \\
\hline $\mathrm{PaCO} 2, \mathrm{kPa}$, mean (SD) & $5.4(0.7)$ & $5.4(0.8)$ & $5.5(0.8)$ & 0.847 \\
\hline Leucocytes, $\times 10^{9} / \mathrm{L}$, mean (SD) & $7.0(1.7)$ & $7.1(1.9)$ & $7.8(2.3)$ & 0.028 \\
\hline GFR, mL/min, mean (SD) & $89(3)$ & $89(3)$ & $79(4)$ & 0.044 \\
\hline 6MWD, meters, mean (SD) & $465(109)$ & $455(123)$ & $365(104)$ & $<0.001$ \\
\hline mMRC > 2, n (\%) & $42(44)$ & $58(51)$ & $47(71)$ & 0.003 \\
\hline AECOPD during last year, $\mathrm{n}(\%)$ & $33(35)$ & $40(36)$ & $28(43)$ & 0.571 \\
\hline
\end{tabular}

*Analysis of variance, Pearson Chi-Square, Fisher's exact test, as appropriate 
Table 2 Mortality rates (MR) by relevant categorical covariates

\begin{tabular}{|c|c|c|c|c|}
\hline \multirow[t]{2}{*}{ Covariate } & \multirow[t]{2}{*}{ m (MR) } & \multirow[t]{2}{*}{ RR } & \multicolumn{2}{|l|}{$p$-value* } \\
\hline & & & unadjusted & Age-adjusted \\
\hline Age, years & & 1.81 & 0.002 & - \\
\hline$<62$ & $8(2.6)$ & & & \\
\hline $62-66$ & $12(4.2)$ & & & \\
\hline$\geq 67$ & $27(8.7)$ & & & \\
\hline Gender & & 1.30 & 0.416 & 0.379 \\
\hline Male & $19(4.5)$ & & & \\
\hline Female & $28(5.8)$ & & & \\
\hline Current smoking & & 0.93 & 0.864 & 0.768 \\
\hline Yes & $11(4.9)$ & & & \\
\hline No & $36(5.3)$ & & & \\
\hline Hypertension & & 1.14 & 0.658 & 0.936 \\
\hline Yes & $19(5.6)$ & & & \\
\hline No & $28(5.0)$ & & & \\
\hline Diabetes & & 2.94 & 0.007 & 0.011 \\
\hline Yes & $6(14.1)$ & & & \\
\hline No & $41(4.8)$ & & & \\
\hline GOLD class & & 2.95 & 0.002 & 0.004 \\
\hline$|-| \mid$ & $10(2.5)$ & & & \\
\hline III-IV & $37(7.4)$ & & & \\
\hline $\mathrm{PaO} 2<8 \mathrm{kPa}$ & & 1.65 & 0.134 & 0.336 \\
\hline Yes & $12(7.7)$ & & & \\
\hline No & $35(4.7)$ & & & \\
\hline Pathologic Q-wave & & 2.39 & 0.028 & 0.071 \\
\hline Yes & $7(11.6)$ & & & \\
\hline No & $40(4.9)$ & & & \\
\hline Antiplatelet therapy & & 0.81 & 0.690 & 0.791 \\
\hline Yes & $4(4.3)$ & & & \\
\hline No & $43(5.3)$ & & & \\
\hline Leucocytes $\geq 7 \times 10^{9} / \mathrm{L}$ & & 2.52 & 0.004 & 0.003 \\
\hline Yes & $34(7.4)$ & & & \\
\hline No & $13(2.9)$ & & & \\
\hline Heart rate $>71$ per min & & 2.48 & 0.004 & 0.004 \\
\hline Yes & $34(7.3)$ & & & \\
\hline No & $13(2.9)$ & & & \\
\hline Systolic blood pressure $>1$ & $40 \mathrm{mmHg}$ & 1.33 & 0.583 & 0.999 \\
\hline No & $6(4.1)$ & & & \\
\hline Yes & $41(5.4)$ & & & \\
\hline GFR & & 0.40 & 0.008 & 0.025 \\
\hline$<45 \mathrm{~mL} / \mathrm{min}$ & $4(24.5)$ & & & \\
\hline $45-60 \mathrm{~mL} / \mathrm{min}$ & $8(6.4)$ & & & \\
\hline$>60 \mathrm{~mL} / \mathrm{min}$ & $35(4.6)$ & & & \\
\hline
\end{tabular}

Table 2 Mortality rates (MR) by relevant categorical covariates (Continued)

\begin{tabular}{lllll}
\hline 6MWD $<450 m$ & & 3.63 & $<0.001$ & 0.002 \\
Yes & $35(8.7)$ & & & \\
No & $12(2.4)$ & & & \\
mMRC $>2$ & & 2.17 & 0.015 & 0.012 \\
Yes & $33(7.0)$ & & & \\
No & $14(3.2)$ & & & \\
*Log-rank test & & & &
\end{tabular}

Overall, the crude MRR across categories of hs-cTnT was 2.1 (95\% CI: 1.4-3.1). The bivariate analyses show that the crude and adjusted MRR were similar, thus, there was no meaningful confounding in the data regarding mortality. The Mantel-Haenszel test did not reveal a $p$-value $<0.05$ for homogeneity for any of the covariates which is why we assume that there was no effect modification of relevant variables.

Age, gender, GOLD class, 6MWD, history of diabetes, leucocyte count and pathological Q-wave were included in the final Cox regression model (Table 4).

There was a positive association between hs-cTnT and mortality ( $\mathrm{p}$ for trend $<0.001$ ). In adjusted analyses, using patients with hs-cTnT $<5.0 \mathrm{ng} / \mathrm{l}$ as the reference, the hazard ratios (95\% confidence intervals) for death were $1.7(0.8-3.9)$ and $2.9(1.2-7.2)$ among patients with hs-cTnT concentrations $5.0-13.9$ and $\geq 14 \mathrm{ng} / \mathrm{L}$, respectively. We also investigated the association between mortality and hs-cTnT expressed as a continuous variable. One unit increase in the natural logarithm of hs-cTnT in the final Cox model was associated with a hazard ratio (95\% CI) of 1.7 (1.2-2.4). We observed no significant changes in the results after exclusion of two patients with hs-cTnT values $>100 \mathrm{ng} / \mathrm{L}$. The global test of the model did not violate the proportional hazards assumption, neither did the single covariates with the exception of gender. However, gender did not influence the association between troponin and mortality.

\section{Discussion}

The main finding in this study is that cTnT-elevation above the $99^{\text {th }}$ percentile in patients with stable COPD without overt CVD is associated with increased mortality, independently of COPD-severity and traditional cardiovascular risk factors.

While the diagnostic properties of elevated troponins are important in patients presenting with chest pain, the properties as a prognostic marker have received considerable interest in acute coronary syndrome, as well as in other conditions such as stable coronary heart disease, heart failure, pulmonary embolism, renal failure, ischemic stroke and sepsis [12, 22-27]. To the best of our knowledge this is the first prospective study to assess the 
Table 3 Mortality, mortality rates, mortality rate ratio expressed as score test for trend for a one unit increase in troponin category, by selected covariates

\begin{tabular}{|c|c|c|c|c|c|}
\hline \multirow[b]{4}{*}{ Covariate } & \multicolumn{3}{|c|}{ High-sensitivity troponin, ng/L } & \multicolumn{2}{|l|}{ MRR (95\% Cl) } \\
\hline & \multirow{3}{*}{$\begin{array}{l}<5.0 \\
(n=95) \\
\mathrm{m}(\mathrm{MR})\end{array}$} & \multirow{3}{*}{$\begin{array}{l}5.0-13.99 \\
(n=114) \\
m(M R)\end{array}$} & \multirow{3}{*}{$\begin{array}{l}\geq 14 \\
(n=66) \\
m(M R)\end{array}$} & & \\
\hline & & & & & \\
\hline & & & & Unadjusted & Adjusted $^{a}$ \\
\hline All, crude & $9(2.8)$ & $17(4.4)$ & $21(11.0)$ & $2.1(1.4-3.1)$ & - \\
\hline \multicolumn{6}{|c|}{ Age at inclusion, years } \\
\hline$<62$ & $2(1.4)$ & $3(2.4)$ & $3(7.0)$ & $2.4(0.9-6.6)$ & \multirow[t]{3}{*}{$1.9(1.3-2.8)$} \\
\hline $62-66$ & $3(3.1)$ & $4(3.2)$ & $5(7.8)$ & $1.7(0.8-3.6)$ & \\
\hline$\geq 67$ & $4(4.6)$ & $10(7.2)$ & $13(15.5)$ & $1.9(1.1-3.1)$ & \\
\hline \multicolumn{6}{|l|}{ Gender } \\
\hline Female & $8(3.7)$ & $9(4.7)$ & $11(15.3)$ & $2.2(1.3-3.8)$ & \multirow[t]{2}{*}{$2.3(1.5-3.4)$} \\
\hline Male & $1(0.9)$ & $8(4.1)$ & $10(8.4)$ & $2.3(1.2-4.3)$ & \\
\hline \multicolumn{6}{|l|}{ Diabetes } \\
\hline Yes & $0(0)$ & $0(0)$ & $6(25.7)$ & $2.5(1.1-5.9)$ & \multirow[t]{2}{*}{$1.9(1.3-2.8)$} \\
\hline No & $9(2.9)$ & $17(4.5)$ & $15(8.9)$ & $1.8(1.2-2.7)$ & \\
\hline \multicolumn{6}{|l|}{ GOLD class } \\
\hline$|-| \mid$ & $2(1.1)$ & $4(2.2)$ & $4(9.5)$ & $3.4(1.3-8.7)$ & \multirow[t]{2}{*}{$1.8(1.2-2.6)$} \\
\hline III-IV & $7(4.6)$ & $13(6.4)$ & $17(11.4)$ & $1.6(1.1-2.4)$ & \\
\hline \multicolumn{6}{|l|}{$\mathrm{PaO} 2<8 \mathrm{kPa}$} \\
\hline Yes & $3(5.3)$ & $2(3.2)$ & $7(19.6)$ & $2.3(1.1-4.8)$ & \multirow[t]{2}{*}{$2.1(1.4-3.0)$} \\
\hline No & $6(2.2)$ & $15(4.6)$ & $14(9.0)$ & $2.1(1.4-3.1)$ & \\
\hline \multicolumn{6}{|l|}{ Pathologic Q-wave } \\
\hline Yes & $1(7.4)$ & $1(5.2)$ & $5(17.9)$ & $1.7(0.7-4.4)$ & \multirow[t]{2}{*}{$2.0(1.4-2.9)$} \\
\hline No & $8(2.6)$ & $16(4.4)$ & $16(10.3)$ & $2.1(1.4-3.2)$ & \\
\hline \multicolumn{6}{|c|}{ Leucocytes $>7 \times 10^{9} / \mathrm{L}$} \\
\hline Yes & $6(3.6)$ & $12(6.7)$ & $16(14.2)$ & $2.0(1.3-3.1)$ & \multirow[t]{2}{*}{$2.0(1.4-2.9)$} \\
\hline No & $3(1.9)$ & $5(2.4)$ & $5(6.4)$ & $1.9(0.9-4.2)$ & \\
\hline \multicolumn{6}{|c|}{ Heart rate, $>71$ per min } \\
\hline Yes & $7(4.8)$ & $11(5.9)$ & $16(12.2)$ & $1.7(1.1-2.6)$ & \multirow[t]{2}{*}{$1.9(1.3-2.8)$} \\
\hline No & $2(1.1)$ & $6(3.0)$ & $5(8.3)$ & $2.9(1.3-6.4)$ & \\
\hline \multicolumn{6}{|l|}{ GFR } \\
\hline$<45 \mathrm{~mL} / \mathrm{min}$ & $0(0)$ & $1(12.1)$ & $3(37.2)$ & $2.8(0.4-19.8)$ & \multirow[t]{3}{*}{$1.9(1.2-3.0)$} \\
\hline $45-60 \mathrm{~mL} / \mathrm{min}$ & $1(1.7)$ & $3(9.3)$ & $4(11.4)$ & $2.2(1.0-5.0)$ & \\
\hline$>60 \mathrm{~mL} / \mathrm{min}$ & $8(3.0)$ & $9(3.7)$ & $14(9.5)$ & $1.9(1.2-2.9)$ & \\
\hline \multicolumn{6}{|l|}{$6 \mathrm{MWD},<450 \mathrm{~m}$} \\
\hline Yes & $7(5.6)$ & $12(7.8)$ & $16(12.6)$ & $1.5(1.0-2.3)$ & \multirow[t]{2}{*}{$1.7(1.2-2.5)$} \\
\hline No & $2(1.0)$ & $5(2.1)$ & $5(7.8)$ & $3.1(1.4-7.3)$ & \\
\hline $\mathrm{mMRC}>2$ & & & & & \\
\hline Yes & $6(4.4)$ & $10(5.0)$ & $17(12.6)$ & $1.8(1.2-2.8)$ & $1.9(1.3-2.8)$ \\
\hline No & $3(1.6)$ & $7(3.7)$ & $4(7.1)$ & $2.2(1.0-4.8)$ & \\
\hline
\end{tabular}

${ }^{\mathrm{a} M a n t e l}$ Haenzel test

association between cTnT and long-term mortality in patients with stable COPD. The present finding is in line with studies in other patient populations in which small increments of circulating concentrations of cTnT are associated with poor outcome above and beyond traditional risk factors $[12,28,29]$. The fact that hs-cTnT in our population was associated with total mortality independently of strong predictors of mortality such as the components of 
Table 4 Multivariate adjusted hazard ratios for all-cause death

\begin{tabular}{|c|c|c|}
\hline Variable & $H R^{a}$ & $95 \% \mathrm{Cl}^{\mathrm{a}}$ \\
\hline \multicolumn{3}{|l|}{ Hs-cTnT, ng/L } \\
\hline$<5$ & 1 & \\
\hline $5-13.9$ & 1.7 & $0.8-3.9$ \\
\hline$\geq 14$ & 2.9 & $1.2-7.2$ \\
\hline$p$ for trend & $<0.001$ & \\
\hline \multicolumn{3}{|l|}{ Age } \\
\hline$<62$ & 1 & \\
\hline $62-66$ & 1.6 & $0.6-3.9$ \\
\hline$\geq 67$ & 2.7 & $1.2-6.0$ \\
\hline $\mathrm{p}$ for trend & 0.002 & \\
\hline Female versus male & 1.9 & $0.99-3.8$ \\
\hline Gold class III/IV versus I/II & 1.8 & $0.84-3.8$ \\
\hline Pathologic Q-wave, yes versus no & 1.5 & $0.62-3.6$ \\
\hline Diabetes, yes versus no & 1.9 & $0.8-5.1$ \\
\hline Leucocyte count $>7 \times 10^{9} / L$, yes versus no & 2.3 & $1.2-4.6$ \\
\hline $6 \mathrm{MWD}<450 \mathrm{~m}$, yes versus no & 1.6 & $0.7-3.3$ \\
\hline
\end{tabular}

${ }^{\mathrm{a}}$ Cox regression analysis

bviolated the proportional hazard assumption, i.e. the HR changed during the follow-up

the BODE index, makes hs-cTnT a possible candidate for early risk prediction in stable COPD patients.

Given that COPD is primarily a pulmonary disease, it is of interest to consider the possible pathophysiological mechanisms underlying cTnT elevation in COPD. cTnT is exclusively synthesized in cardiomyocytes, and the presence of cTnT in serum implicates leakage of cTnT into the circulation by cell damage or increased cell turnover. The most common causes for chronic, lowgrade cTnT-increase are ischemic heart disease and conditions characterized by increased cardiac strain [30]. The participants in the present study were without overt CVD, but we cannot exclude the possibility that patients with increases in cTnT had undiagnosed coronary artery disease. Indeed 20 (7\%) of the patients had a pathological Q-wave on the ECG, but interestingly this was not significantly related to hs-cTnT concentrations. Nterminal prohormone of B-type natriuretic peptide (NTproBNP), an indicator of heart failure, was not measured in all participants, but a previous analysis in a subgroup $(n=101)$ showed normal NT-proBNP levels and no association with cTnT [16].

Pertinent to the hypothesis that COPD might be a risk factor for CVD, factors known to be associated with secondary cardiovascular effects, such as systemic hypoxemia and systemic inflammation, were evaluated. In the present study only 45 (16\%) of the patients had arterial hypoxemia, and we found no statistically significant association between partial pressure of oxygen and troponin or mortality. Leucocyte count as an indicator of elevated baseline inflammation was associated with increased levels of troponin and risk of death in the present study. Such associations have been reported earlier [16, 31]. Inflammatory activity might promote the development and worsening of subclinical atherosclerotic disease and thereby prognosis in this population. There is also a possibility that cTnT elevation is mediated by an inflammatory effect on the cardiomyocytes. In that case, leukocyte count represents a mediator and should not been included as a covariate [32]. A higher inflammatory state has also been linked to worse prognosis and more frequent exacerbations in COPD [33].

Another possible mechanism underlying $\mathrm{cTnT}$ elevation in stable COPD might be increased right ventricular strain associated with pulmonary hypertension [34]. Hattori et al. have described an association between hs-cTnT with right heart pressure in stable COPD [31]. It is conceivable that the involvement of the right heart accounts for both elevated hs-cTnT and increased mortality in stable COPD independently of lung function.

The current study extends previous data concerning the prognostic value of hs-cTnT in patients with acute exacerbation of COPD. However, although elevated cTn concentrations are associated with poor outcome, it is not established how clinicians should approach this situation neither in COPD nor in other patient groups.

\section{Study limitations}

In order to further evaluate the discriminative power of cTnT in risk stratification, larger study samples are needed. Serial hs-cTnT measurement would provide us with a better possibility to evaluate the associations between cTnT and mortality in relation to COPD-progression and other cardiovascular risk factors. The study would have benefitted from baseline cardiac imaging, both with regard to undiagnosed coronary heart disease and myocardial function. A stable state was defined as $<3$ weeks since last exacerbation. This is a shorter period than in several other COPDstudies. However, excluding patients having an exacerbation during the last 3 months prior to inclusion did not change the main results (data not shown). We lack information regarding the cause of death, which could have given us additional insight in the relation between $\mathrm{CTnT}$ and cardiovascular deaths.

\section{Conclusion}

cTnT, measured by a high sensitivity assay, was associated with increased all-cause mortality, independently of COPD-severity.

\section{Additional file}

Additional file 1: Data set. (XLS $110 \mathrm{~kb}$ ) 


\section{Abbreviations}

6MWD: 6-minutes walk-test; BMl: Body mass index; Cl: Confidence intervals; COPD: Chronic obstructive pulmonary disease; CVD: Cardiovascular disease; ECG: Electrocardiography; FEV1: Forced expiratory volume during $1^{\text {st }}$ second; FVC: Forced vital capacity; GFR: Glomerular filtration rate; GOLD: Global initiative of obstructive lung disease; HR: Hazard ratio; hs: High-sensitivity; LVH: Left ventricular hypertrophy; Ml: Myocardial infarction; mMRC: Modified Medical Research Council; MRR: Mortality rate ratio; NT-proBNP: N-terminal pro B-type natriuretic peptide; SD: Standard deviation; TnT/Tnl: Troponin T//

\section{Acknowledgments}

We want to thank Vigdis Bakkelund, Marit Jørgensen and Annika Lorentzen for invaluable assistance in the data collection at the Akershus University Hospital and Grethe Dahle and colleagues at Glittre. We are also thankful for the assistance by Ivar Ellingsen to obtain the mortality data.

\section{Funding}

This study was supported by grants from the Norwegian Extra Foundation for Health and Rehabilitation and The Norwegian Association of Heart and Lung Patients.

\section{Availability of data and materials}

The dataset supporting the conclusions of this article is included within the article (and its Additional file 1).

\section{Authors' contributions}

All authors read and approved the final manuscript. AN: participated in planning the design, collecting, analyses and interpretation of data, as well as drafting of the manuscript, GE: was involved in data analyses and interpretation, drafting of the manuscript. ADH contributed to data collection, VS was involved in the design of the study and drafting of the manuscript, NHH contributed to data collection and analyses, NK contributed to data collection, TO was the principal investigator, designed the study, contributed to analyses of the data and drafting of the manuscript.

\section{Competing interests}

TO has received speaker and/or consultancy honoraria from Abbott Diagnostics, Roche Diagnostics, Novartis and research support from Abbott Diagnostics, AstraZeneca, Thermo Fisher Scientific, and Biomedica. GE has received research grants from Astra Zeneca and speaker honorarium from Takeda. AN has received speaker honorarium from Astra Zeneca and Boehringer Ingelheim. NHH has received speaker honorarium and/or research grants from Boehringer Ingelheim, GlaxoSmithKline and Takeda. The other authors declare no reported competing interest.

\section{Consent for publication}

Not applicable.

\section{Ethics approval and consent to participate}

The study was approved by the regional ethics committee 2009-684 and performed according to the Declaration of Helsinki. Written informed consent was obtained from all participants before study commencement.

\section{Author details}

'Department of Imaging, Akershus University Hospital, Lørenskog, Norway. 2Division of Medicine, Akershus University Hospital, Lørenskog, Norway. ${ }^{3}$ Department of Cardiology, Oslo University Hospital, Oslo, Norway. ${ }^{4}$ Glittreklinikken, LHL-klinikkene, Hakadal, Norway. Institute of Clinical Medicine, University of Oslo, Oslo, Norway.

Received: 10 June 2016 Accepted: 13 November 2016

Published online: 25 November 2016

\section{References}

1. Vestbo J, Hurd SS, Agusti AG, Jones PW, Vogelmeier C, Anzueto A, Barnes PJ, Fabbri LM, Martinez FJ, Nishimura M, et al. Global strategy for the diagnosis, management, and prevention of chronic obstructive pulmonary disease: GOLD executive summary. Am J Respir Crit Care Med. 2013;187(4):347-65.
2. Chatila WM, Thomashow BM, Minai OA, Criner GJ, Make BJ. Comorbidities in Chronic Obstructive Pulmonary Disease. Proc Am Thorac Soc. 2008;5(4):549-55.

3. Finkelstein J, Cha E, Scharf SM. Chronic obstructive pulmonary disease as an independent risk factor for cardiovascular morbidity. Int J Chron Obstruct Pulmon Dis. 2009;4:337-49.

4. Mannino DM, Thorn D, Swensen A, Holguin F. Prevalence and outcomes of diabetes, hypertension and cardiovascular disease in COPD. Eur Respir J. 2008;32(4):962-9.

5. Müllerova H, Agusti A, Erqou S, Mapel DW. Cardiovascular comorbidity in copd: Systematic literature review. Chest. 2013;144(4):1163-78.

6. Campo G, Guastaroba P, Marzocchi A, Santarelli A, Varani E, Vignali L, Sangiorgio P, Tondi S, Serenelli C, De Palma R, et al. Impact of COPD on longterm outcome after ST-segment elevation myocardial infarction receiving primary percutaneous coronary intervention. Chest. 2013;144(3):750-7.

7. Campo G, Pavasini R, Malagu M, Mascetti S, Biscaglia S, Ceconi C, Papi A, Contoli M. Chronic obstructive pulmonary disease and ischemic heart disease comorbidity: overview of mechanisms and clinical management. Cardiovasc Drugs Ther. 2015;29(2):147-57.

8. Maclay JD, MacNee W. Cardiovascular disease in COPD: mechanisms. Chest. 2013;143(3):798-807.

9. Thygesen K, Alpert JS, Jaffe AS, Simoons ML, Chaitman BR, White HD. Third universal definition of myocardial infarction. J Am Coll Cardiol. 2012;60(16):1581-98.

10. Jaffe AS, Babuin L, Apple FS. Biomarkers in acute cardiac disease: the present and the future. J Am Coll Cardiol. 2006;48(1):1-11.

11. Mingels AM, Jacobs LH, Kleijnen WW, Laufer EM, Winkens B, Hofstra L, Wodzig WK, van Dieijen-Visser MP. Cardiac troponin T elevations, using highly sensitive assay, in recreational running depend on running distance. Clin Res Cardiol. 2010;99(6):385-91.

12. Omland T, de Lemos JA, Sabatine MS, Christophi CA, Rice MM, Jablonski KA, Tjora S, Domanski MJ, Gersh BJ, Rouleau JL, et al. A sensitive cardiac troponin T assay in stable coronary artery disease. N Engl J Med. 2009;361 (26):2538-47.

13. Latini R, Masson S, Anand IS, Missov E, Carlson M, Vago T, Angelici L, Barlera $S$, Parrinello G, Maggioni AP, et al. Prognostic value of very low plasma concentrations of troponin $T$ in patients with stable chronic heart failure. Circulation. 2007;116(11):1242-9.

14. Chang CL, Robinson SC, Mills GD, Sullivan GD, Karalus NC, McLachlan JD, Hancox RJ. Biochemical markers of cardiac dysfunction predict mortality in acute exacerbations of COPD. Thorax. 2011;66(9):764-8.

15. Hoiseth AD, Neukamm A, Karlsson BD, Omland T, Brekke PH, Soyseth V. Elevated high-sensitivity cardiac troponin $\mathrm{T}$ is associated with increased mortality after acute exacerbation of chronic obstructive pulmonary disease. Thorax. 2011;66(9):775-81.

16. Neukamm AM, Hoiseth AD, Hagve TA, Soyseth V, Omland T. High-sensitivity cardiac troponin T levels are increased in stable COPD. Heart. 2013;99(6):382-7.

17. Campo G, Pavasini R, Malagù M, Punzetti S, Napoli N, Guerzoni F, Papi A, Ceconi C, Contoli M. Relationship between Troponin Elevation, Cardiovascular History and Adverse Events in Patients with acute exacerbation of COPD. COPD. 2015;12(15):560-7.

18. Pavasini R, d'Ascenzo F, Campo G, Biscaglia S, Ferri A, Contoli M, Papi A, Ceconi C, Ferrari R. Cardiac troponin elevation predicts all-cause mortality in patients with acute exacerbation of chronic obstructive pulmonary disease: Systematic review and meta-analysis. Int J Cardiol. 2015;191:187-93.

19. Holmedahl NH, Overland B, Fondenes O, Ellingsen I, Hardie JA. Sleep hypoventilation and daytime hypercapnia in stable chronic obstructive pulmonary disease. Int J Chron Obstruct Pulmon Dis. 2014;9:265-75.

20. Neukamm A, Hoiseth AD, Einvik G, Lehmann S, Hagve TA, Soyseth V, Omland T. Rosuvastatin treatment in stable chronic obstructive pulmonary disease (RODEO): a randomized controlled trial. J Intern Med. 2015;278(1):59-67.

21. Cockcroft DW, Gault MH. Prediction of creatinine clearance from serum creatinine. Nephron. 1976;16(1):31-41.

22. Gaggin HK, Januzzi Jr JL. Biomarkers and diagnostics in heart failure. Biochim Biophys Acta. 2013;1832(12):2442-50.

23. Omland T, Røsjø H, Giannitsis E, Agewall S. Troponins in heart failure. Clin Chim Acta. 2015;443:78-84

24. Filusch A, Giannitsis E, Katus HA, Meyer FJ. High-sensitive troponin T: a novel biomarker for prognosis and disease severity in patients with pulmonary arterial hypertension. Clin Sci. 2010;119(5):207-13.

25. Lankeit M, Friesen D, Aschoff J, Dellas C, Hasenfuss G, Katus H, Konstantinides S, Giannitsis E. Highly sensitive troponin T assay in 
normotensive patients with acute pulmonary embolism. Eur Heart J. 2010;31(15):1836-44.

26. Vasile VC, Chai H-S, Abdeldayem D, Afessa B, Jaffe AS. Elevated Cardiac Troponin T Levels in Critically III Patients with Sepsis. Am J Med. 2013;126(12):1114-21.

27. Scheitz JF, Mochmann H-C, Erdur H, Tütüncü $S$, Haeusler KG, Grittner $U$, Laufs $\mathrm{U}$, Endres $\mathrm{M}$, Nolte $\mathrm{CH}$. Prognostic relevance of cardiac troponin $\mathrm{T}$ levels and their dynamic changes measured with a high-sensitivity assay in acute ischaemic stroke: Analyses from the TRELAS cohort. Int J Cardiol. 2014;177(3):886-93.

28. de Lemos JA, Drazner MH, Omland T, Ayers CR, Khera A, Rohatgi A, Hashim I, Berry JD, Das SR, Morrow DA, et al. Association of troponin T detected with a highly sensitive assay and cardiac structure and mortality risk in the general population. JAMA. 2010;304(22):2503-12.

29. Neeland IJ, Drazner MH, Berry JD, Ayers CR, de Filippi C, Seliger SL, Nambi V, McGuire DK, Omland T, de Lemos JA. Biomarkers of Chronic Cardiac Injury and Hemodynamic Stress Identify a Malignant Phenotype of Left Ventricular Hypertrophy in the General Population. J Am Coll Cardiol. 2013;61(2):187-95.

30. Omland T. New features of troponin testing in different clinical settings. J Intern Med. 2010;268(3):207-17.

31. Hattori K, Ishii T, Motegi T, Kusunoki Y, Gemma A, Kida K. Relationship between serum cardiac troponin T level and cardiopulmonary function in stable chronic obstructive pulmonary disease. Int J Chron Obstruct Pulmon Dis. 2015;10:309-20.

32. Rothman KJ, Greenland S, Lash TL: Modern Epidemiology, vol. 3rd Edition. Philadelphia; 2008

33. Agusti A, Edwards LD, Rennard SI, MacNee W, Tal-Singer R, Miller BE, Vestbo J, Lomas DA, Calverley PM, Wouters E, et al. Persistent systemic inflammation is associated with poor clinical outcomes in COPD: a novel phenotype. PLoS One. 2012;7(5):e37483.

34. Hilde JM, Skjorten I, Grotta OJ, Hansteen V, Melsom MN, Hisdal J, Humerfelt S, Steine K. Right ventricular dysfunction and remodeling in chronic obstructive pulmonary disease without pulmonary hypertension. J Am Coll Cardiol. 2013;62(12):1103-11.

\section{Submit your next manuscript to BioMed Central} and we will help you at every step:

- We accept pre-submission inquiries

- Our selector tool helps you to find the most relevant journal

- We provide round the clock customer support

- Convenient online submission

- Thorough peer review

- Inclusion in PubMed and all major indexing services

- Maximum visibility for your research

Submit your manuscript at www biomedcentral.com/submit
(O) BioMed Central 